\title{
INTERNALISASI PESAN MULTIKULTURAL PADA ORGANISASI PESANTREN PUTRI STAIN JEMBER
}

\author{
Musyarofah \\ Dosen Ilmu Pengetahuan Sosial IAIN Jember \\ musyarofahhrt@yahoo.co.id
}

\begin{abstract}
Multicultural education focuses on the process of developing Islamic boarding school students' ability to comprehend, admit, respect, and live harmonically and peacefully in different reality. Islamic boarding school has important role to internalize multicultural values. This research was aimed to know the internalization of multicultural education among Islamic boarding school students in the Islamic boarding school Organization for female at State Islamic Studies Institute (STAIN) Jember. This research used qualitative approach where the tutor, committee, and the students of this organization became the research subject. This research revealed that the internalization of multicultural education in curriculum was implemented in diniyah and Islamic literature study (kajian kitab) by integrating multicultural values in the study of Taisirul Kholaq, Tadhib, Al-Akhlaqu Lil Banats, Fiqhun nisa, Kifayatu al-atsqiya, and Fathul Qorib book. Integration of multicultural value in educational process was implemented in some matters: (1) creating Islamic boarding school culture that respected the difference; (2) Educational activity implemented by kyai emphasized on the importance of honor aspect toward humanity. (3) The enactment of regulation and punishment dedicated to all students, without seeing their background and socio-economic status.
\end{abstract}

Keywords: Internalization, Message, Multicultural

\begin{abstract}
Abstrak
Pendidikan multikultural memfokuskan pada proses pengembangan kemampuan santri untuk memahami, mengakui, menghormati, dan hidup secara nyaman dan harmonis dalam perbedaan. Penelitian bertujuan untuk mengetahui internalisasi pendidikan multikultural pada santri di organisasi pesantren puteri STAIN Jember, dengan menggunakan pendekatan kualitatif serta subjek penelitian pengasuh, pengurus dan santri. Hasil penelitian internalisasi pendidikan multikultural pada kurikulum dilakukan dengan mengintegrasikan nilai diniyah dengan kitab Taisirul Kholaq, Tadhib, Al-Akhlaqu Lil Banats, Fiqhun nisa, Kifayatu al-atsqiya, dan Fathul Qorib. Pengasuhan dilaksanakan melalui beberapa hal: (1) Menciptakan kultul pesantren yang menghargai perbedaan; (2) Kegiatan pengasuhan yang dilakukan kyai menekankan pentingnya aspek penghargaan terhadap kemanusiaan. (3) Pemberlakuan tata tertib dan sanksi yang diperuntukkan bagi semua santri, tanpa memandang latar belakang status sosial ekonomi.
\end{abstract}

Kata Kunci: Internalisasi, Pesan, Multikultural

\section{Pendahuluan}

Indonesia merupakan salah satu negara multikultural terbesar di dunia. Masyarakat Indonesia demikian majemuk baik secara etnis, geografis, kultur, maupun agama. Realitas keragaman ini harus disikapi dengan arif, terbuka, dan dewasa. Jika keterbukaan dan kedewasaan dikesampingkan, keragaman budaya bangsa akan 
Inject, Interdisciplinary Journal of Communication, Vol. 1, No. 2, Desember 2016:181-202

membawa konsekuensi munculnya berbagai persoalan seperti kekerasan, diskriminasi terhadap kelompok lain, eksklusivisme, separatisme, dan hilangnya rasa kemanusiaan untuk menghormati hak-hak orang lain, dan sebagainya. Untuk itu pemahaman yang mendalam tentang makna perbedaan sebagai keniscayaan akan membuat bangsa ini aman, dan sejahtera. Dalam konteks ini, pendidikan multikultural menjadi sangat penting.

Pendidikan multikultural difokuskan pada proses pengembangan seluruh potensi manusia yang menghargai pluralitas dan heterogenitas sebagai konsekuensi keragaman budaya, etnis, suku, dan agama (Dawam, 2003: 99). Pendidikan multikultural memiliki 3 (tiga) karakteristik yaitu: Pertama, pendidikan multikultural berprinsip pada demokrasi, kesetaraan, dan keadilan; Kedua, pendidikan multikultural berorientasi pada kemanusiaan, kebersamaan, dan kedamaian; Ketiga, pendidikan multikultural mengembangkan sikap mengakui, menerima, dan menghargai keragaman budaya. Dengan karakteristik tersebut, pendidikan multikultural dapat mencetak peserta didik mempunyai kearifan lokal, mempunyai jiwa toleransi, atau menghasilkan peserta didik yang berpandangan inklusif terhadap realitas masyarakat yang beragam.

Dalam konteks yang lebih luas, pendidikan multikultural inilah yang akan mengantarkan dan membangun manusia Indonesia mempunyai jiwa nasionalisme dan akhirnya dapat mempertahankan keutuhan bangsa dari ancaman disintegrasi. Pendidikan multikultural harus diberikan pada semua jalur pendidikan baik formal, nonformal, maupun informal.

Pesantren sebagai institusi pendidikan islam yang berakar dari masyarakat dan keberadaannya diakui oleh masyarakat, memiliki andil yang besar dalam menanamkan nilai-nilai inti dari pendidikan multikultural seperti demokrasi, humanisme, pluralisme, dan nilai-nilai keberagamaan yang inklusif dan sebagainya. Selama ini pesantren telah terbukti memberikan sumbangan dalam mewujudkan idealisme pendidikan nasional yaitu mewujudkan kualitas sumber daya manusia yang handal.

Pesantren yang akrab dengan khazanah klasik mampu melahirkan sikap tasamuh (lapang dada), tawazun (keseimbangan), dan i'tidal (adil). Pesantren mampu menjalankan fungsi dan peran sosial yaitu: (1) sebagai tempat terselenggaranya kegiatan transmisi dan transfer ilmu pengetahuan Islam, (2) sebagai pusat pemeliharaan tradisi Islam, dan (3) sebagai pusat penyiapan dan penciptaan kader-kader Islam (Azra, 2003: 149). 
Organisasi Pesantren Putri STAIN Jember merupakan salah satu manifestasi dari pondok pesantren tentunya juga memiliki peran dalam menginternalisasikan nilai-nilai multikultural pada santri. Hal tersebut dapat dilihat melalui peran yang dilakukan oleh pengasuh, ustadz/ustadzah dan pengurus, penerapan aturan/sanksi, kurikulum dan sebagainya. Misalnya dalam penerimaan santri (mahasiswi semester I-VI dapat masuk dan menjadi santri Organisasi Pesantren Putri tanpa memandang asal daerah); aturan dan sanksi diberlakukan pada semua santri tanpa membedakan latar belakang santri, status ekonomi dan sebagainya. Dari studi pendahuluan dapat diketahui bahwa nilainilai multikulturalisme sudah ditanamkan di Organisasi Pesantren Putri STAIN Jember, sekalipun belum optimal.

\section{Permasalahan}

Penelitian ini memfokuskan diri pada bagaimana internalisasi pendidikan multikultural pada santri di Organisasi Pesantren Puteri STAIN Jember. Adapun sub fokus dalam penelitian ini adalah (1) Bagaimana internalisasi pendidikan multikultural pada kurikulum di Organisasi Pesantren Puteri STAIN Jember? (2) Bagaimana integrasi nilai-nilai multikultural dalam pengasuhan di Organisasi Pesantren Putri STAIN Jember? (3) Bagaimana peran pengasuh, dan pengurus dalam menginternalisasikan nilai-nilai multikultural pada diri santri di Organisasi Pesantren Putri STAIN Jember?

\section{Sejarah Pendidikan Multikultural di Indonesia}

Wacana pentingnya pendidikan multikultural di Indonesia yang digemakan melalui berbagai simposium dan workshop di atas, menurut para penggagasnya, dilatarbelakangi oleh fakta bahwa Indonesia merupakan negara yang memiliki banyak problem tentang eksistensi sosial, etnik dan kelompok keagamaan yang beragam. Problem tersebut disebabkan oleh adanya upaya penyeragaman dalam berbagai aspek kehidupan yang dilakukan oleh pemerintah pada masa Orde Baru.

Selama Orde Baru berkuasa, pemerintah mengabaikan terhadap perbedaan yang ada, baik dari segi suku, bahasa, agama, maupun budayanya. Semboyan Bhineka Tunggal Ika pun diterapkan secara berat sebelah. Artinya, semangat ke-ika-an lebih menonjol daripada semangat kebhinekaannya dalam pengelolaan Negara Indonesia. Pengelolaan negara dengan penekanan pada semangat ke-ika-an daripada semangat ke- 
Inject, Interdisciplinary Journal of Communication, Vol. 1, No. 2, Desember 2016:181-202

bhineka-an tersebut sangat mewarnai konsep dan praktik pendidikan di Indonesia (Aly, 2011: 98).

Dalam forum konferensi internasional di atas, Azyumardi Azra mengemukakan bahwa pengelolaan negara Indonesia dengan politik monokulturalisme oleh pemeritah Orde Baru telah menghancurkan local cultural geniuses. Azra mencontohkan bahwa hilangnya tradisi 'pela gandong' di Ambon dan 'republik nagari' di Sumatra Barat merupakan fakta-fakta historis yang diakibatkan oleh penerapan politik monokulturalisme pemerintah Orde Baru. Padahal, menurutnya, sistem atau tradisi sosio-kultural lokal seperti ini merupakan kekayaan kultural yang tidak ternilai, bukan hanya bagi masyarakat sendiri tetapi juga bagi masyarakat yang lain.

Lebih jauh, Azra menambahkan bahwa local geniuses berfugsi sebagai mekanisme pertahanan dan sekaligus early warning system yang dapat mengantisipasi ancaman terhadap keutuhan tradisi dan sistem sosio-kultural. Hal ini berarti bahwa penghilangan local geniuses dapat menghancurkan integrasi dan sosio-kultural masyarakat yang bersangkutan. Politik monokulturalisme yang telah menghancurkan local geniuses ini, pada gilirannya akan mengakibatkan terjadi kerentanan dan disintegrasi sosial-budaya lokal. Baginya, konflik dan kekerasan yang bernuansa etnis dan agama, yang khususnya marak sejak 1996, tidak terlepas dari hancurnya local geniuses tersebut.

Memperhatikan kasus dan kenyataan konfliktual tersebut, Azra merekomendasikan pentingnya merekonstruksi kembali 'kebudayaan nasional Indonesia' yang dapat menjadi 'integrating force' yang mengikat seluruh keragaman etnis dan budaya tersebut. Baginya, pembentukan masyarakat multikultural Indonesia yang demokratis tidak bisa secara taken for granted atau trial and error. Sebaliknya harus diupayakan secara sistematis, programatis, integratif,dan berkesinambungan sebagai upaya strategis yaitu salah satunya dengan pendidikan multikultural terutama melalui beberapa mata pelajaran yang diberikan oleh lembaga pendidikan baik formal, non formal bahkan informal (Aly, 2011: 100).

\section{Pengertian Pendidikan Multikultural}

Secara etimologis, multikulturalisme dibentuk dari kata multi (banyak), kultur (budaya), dan isme (aliran/paham). Secara hakiki, dalam kata itu terkandung pengakuan akan martabat manusia yang hidup dalam komunitasnya dengan kebudayaan masingmasing yang unik. Dengan demikian, setiap individu merasa dihargai sekaligus merasa 
Musyarofah, Internalisasi Pesan Multikultural Pada Organisasi Pesantren...

bertanggung jawab untuk hidup bersama komunitasnya. Pengingkaran suatu masyarakat terhadap kebutuhan untuk diakui merupakan akar dari segala ketimpangan dalam berbagai bidang kehidupan (Mahfud, 2009: 75).

Ngainun Naim dan Achmad Sauqi (2011:50) menjelaskan bahwa dalam pendidikan multikultural selalu muncul dua kata kunci yaitu: pluralitas dan kultural. Pemahaman terhadap pluralitas mencakup segala perbedaan dan keragaman, apapun bentuk perbedaan dan keragamannya. Sedangkan kultul itu sendiri tidak bisa terlepas dari empat tema penting yaitu aliran agama, ras, etnis, suku, dan budaya. Pendidikan multikultural diartikan sebagai perspektif yang mengakui realitas politik, sosial, dan ekonomi yang dialami oleh masing-masing individu dalam pertemuan manusia yang kompleks dan beragam secara kultur, dan merefleksikan pentingnya budaya, ras, seksualitas dan gender, etnisitas, agama, status sosial, dan ekonomi. Secara luas pendidikan multikultural itu mencakup seluruh siswa tanpa membeda-bedakan kelompok-kelompoknya seperti gender, etnic, ras, budaya, strata sosial, dan agama (Mahfud, 2009:177).

Sonia Nieto, mengungkapkan pendidikan multikultural adalah proses pendidikan yang komperhensif dan mendasar bagi semua peserta didik. Jenis pendidikan ini menentang bentuk rasisme dan segala bentuk diskriminasi di sekolah, masyarakat dengan menerima serta mengafirmasi pluralitas (etnik, ras, bahasa, agama, ekonomi, gender dan lain sebagainya) yang terefleksikan di antara peserta didik, komunitas mereka, dan guru-guru. Menurutnya, pendidikan multikultur ini haruslah melekat dalam kurikulum dan strategi pengajaran, termasuk juga dalam setiap interaksi yang dilakukan di antara para guru, murid dan keluarga serta keseluruhan suasana belajarmengajar.

Pendapat senada diungkapkan Bennet (1999:12) bahwa konsep pendidikan multukultural meliputi gerakan menuju pencapaian pemberian kesempatan yang sama bagi setiap siswa, kurikulum yang dapat mengembangkan pemahaman tentang perbedaan budaya, proses yang memfasilitasi siswa untuk menjadi orang yang secara budaya kompeten, dan komitmen untuk melawan kesewenangan diskriminasi dan ketidakadilan sosial.

H.A.R Tilaar (2002) menyatakan bahwa fokus program pendidikan multikultural tidak semata-mata diarahkan pada kelompok rasial, agama dan kultural dominan atau mainstream. Pendidikan multikultural memfokuskan diri pada proses pengembangan kemampuan peserta didik untuk memahami, mengakui, menghormati, dan hidup secara nyaman dan harmonis dalam realitas perbedaan. Pendidikan multikultural merupakan 
Inject, Interdisciplinary Journal of Communication, Vol. 1, No. 2, Desember 2016:181-202

pendidikan yang dapat mencetak peserta didik mempunyai kearifan lokal, mempunyai jiwa toleransi, atau menghasilkan peserta didik yang berpandangan inklusif penting untuk wujudkan.

Hal senada diungkapkan Ngainun Naim dan Achmad Sauqi (2011:191) bahwa pendidikan pluralis-multikultural merupakan pendidikan yang memberikan penekanan pada proses penanaman cara hidup yang saling menghormati, tulus, toleran terhadap keanekaragaman budaya yang hidup di tengah-tengah masyarakat. Pendidikan multikultural difokuskan pada proses pengembangan seluruh potensi manusia yang menghargai pluralitas dan heterogenitas sebagai konsekuensi keragaman budaya, etnis, suku, dan agama (Ainurrafiq Dawam, 2003:99). Menurut Bennett ada empat nilai inti yang dikembangkan dalam pendidikan multikultural yaitu: Pertama, apresiasi terhadap kenyataan pluralitas budaya dalam masyarakat; Kedua, Pengakuan terhadap harkat, martabat dan hak asasi manusia; Ketiga, Pengembangan tanggungjawab masyarakat dunia; Keempat, pengembangan tanggungjawab manusia terhadap planet bumi (Naim dan Sauqi, 2011:213).

Adapun tujuan pendidikan multikultural dapat dibedakan menjadi tiga macam tujuan, yaitu: tujuan yang berkaitan dengan sikap, pengetahuan, dan pembelajaran (Lawrence J. Saha, 1997:349). Tujuan pendidikan multikultural yang berkaitan dengan aspek sikap (attitudinal goals) adalah untuk mengembangkan kesadaran dan kepekaan kultural, toleransi kultural, penghargaan terhadap identitas kultural, sikap responsif terhadap budaya, keterampilan untuk menghindari dan meresolusi konflik.

Tujuan pendidikan multikultural yang berkaitan dengan aspek pengetahuan (cognitive goals) adalah untuk memperoleh pengetahuan tentang bahasa dan budaya orang lain, dan kemampuan untuk menganalisis dan menerjemahkan perilaku kultural, dan pengetahuan tentang kesadaran perspektif kultural. Sedangkan tujuan pendidikan multikultural yang berkaitan dengan pembelajaran (instructional goals) adalah untuk memperbaiki distorsi, stereotip, dan kesalahpahaman tentang kelompok etnik dalam buku teks dan media pembelajaran; memberikan berbagai strategi untuk mengarahkan perbedaan di depan orang, memberikan alat-alat konseptual untuk komunikasi antar budaya; mengembangkan keterampilan interpersonal; memberikan teknik-teknik evaluasi; membantu klarifikasi nilai; dan menjelaskan dinamika kultural.

Pendidikan berparadigma multikulturalisme jelas akan mengarahkan anak didik untuk bersikap dan berpandangan toleran dan inklusif terhadap realitas masyarakat yang 
Musyarofah, Internalisasi Pesan Multikultural Pada Organisasi Pesantren...

beragam (Mahfud, 2009:185). Pendidikan multikultural menawarkan kepada peserta didik cara pandang dan sikap dalam menghadapi perbedaan dan heterogenitas kelompok etnis, relasi gender, hubungan antaragama, kelompok kepentingan, kebudayaan, dan subkultural. Pendidikan multikultural memiliki peran yang sangat strategis untuk mengelola kemajemukan yang ada secara kreatif.

\section{Karakteristik Pendidikan Multikultural}

Abdullah Aly (2011:109) mengemukakan bahwa karakteristik pendidikan multikultural ada tiga yaitu: Pertama, pendidikan multikultural berprinsip pada demokrasi, kesetaraan, dan keadilan; Kedua, pendidikan multikultural berorientasi pada kemanusiaan, kebersamaan, dan kedamaian; Ketiga, pendidikan multikultural mengembangkan sikap mengakui, menerima, dan menghargai keragaman budaya.

Pendidikan multikultural berprinsip pada demokrasi, kesetaraan, dan keadilan. Karakteristik ini, sejalan program UNESCO tentang education for all (EFA) yang memberikan peluang yang sama kepada semua anak untuk memperoleh pendidikan. Menurut Dede Rosyada (2004), hal tersebut tidak sebatas pada pemberian kesempatan yang sama kepada semua anak untuk memperoleh pendidikan, melainkan juga semua peserta didik harus memperoleh perlakuan yang sama nuntuk memperoleh pelajaran di kelas. Pendidikan multikultural akan menjamin semua peserta didik memperoleh perhatian yang sama tanpa membedakan latar belakang warna kulit, etnik, agama, bahasa, budaya, pandai, bodoh, rajin, dan malas.

Berorientasi pada kemanusiaan, kebersamaan, dan kedamaian. Kemanusiaan (humanity) dipahami sebagai nilai yang menempatkan peningkatan pengembangan manusia, keberadaannya, dan martabatnya sebagai pemikiran dan tindakan manusia tertinggi. Nimrod Aloni (Aly, 2011:114) menjelaskan ada tiga prinsip dalam kemanusian yaitu: (1) otonomi, rasional, dan penghargaan untuk semua orang; (2) kesetaraan dan kebersamaan; dan (3) komitmen untuk membantu semua orang dalam pengembangan potensinya. Orientasi kemanusiaan dalam pendidikan multikultural relevan dengan konsep hablum min al-naas. Menurut Abdulaziz Sachedina, konsep ini menempatkan manusia pada dua posisi meliputi: Pertama manusia sebagai makhluk terbaik (ahsanu taqwiim); Kedua, manusia harus tunduk kepada hukum Allah (Aly, 2011:215).

Kebersamaan (cooperation), dipahami sebagai sikap seseorang terhadap orang lain, atau sikap seseorang terhadap kelompok dan komunitas. Nilai kebersamaan dalam islam 
Inject, Interdisciplinary Journal of Communication, Vol. 1, No. 2, Desember 2016:181-202

relevan dengan konsep ta'aaruf (saling mengenal), dan ta'aawun (saling menolong). Orientasi kebersamaan sejalan dengan pilar keempat pendidikan UNESCO yaitu learning live together, yang berarti kemampuan untuk hidup bersama dengan orang lain yang berbeda suku, etnik, bahasa, budaya, dan agama.

Mengembangkan sikap mengakui, menerima, dan menghargai keragaman. Sikap menerima, mengakui, dan menghargai keragaman diperlukan dalam kehidupan sosial di masyarakat majemuk. Penerimaan, pengakuan, dan penghargaan terhadap keragaman merupakan sikap sosial yang diperlukan dalam membangun hubungan sosial yang harmonis di dalam masyarakat majemuk.

Neito (2002), seperti dikutip oleh de Valenzuela (2010) menjelaskan tujuh karakteristik pendidikan multikultur sebagai berikut: (1) Pendidikan multikultur adalah pendidikan anti-rasis. (2) Pendidikan multikultur adalah pendidikan dasar. (3) Pendidikan multikultur adalah penting bagi semua siswa. (4) Pendidikan multikultur adalah luas (pervasive). (5) Pendidikan multikultur adalah keadilan sosial. (6) Pendidikan multikultur adalah proses. (7) Pendidikan multikultur adalah pedagogi kritis

Sedangkan menurut Choirul Mahfud (2013:187) mengemukakan ciri-ciri pendidikan multikulturalisme antara lain: (1) Tujuannya membentuk 'manusia budaya', dan menciptakan 'masyarakat berbudaya'. (2) Materi pendidikan multikultural mengajarkan nilai-nilai luhur kemanusiaan, nilai-nilai bangsa, dan nilai kelompok etnis (kultural). (4) Metodenya demokratis, menghargai aspek-aspek perbedaan dan keberagaman budaya bangsa dan kelompok etnis (multikultural). (5) Evaluasi pendidikan multikultural ditentukan pada penilaian terhadap tingkah laku anak didik yang meliputi persepsi, apresiasi, dan tindakan terhadap budaya lain.

Dalam pelaksanaan pendidikan multikultural, Banks menjelaskan ada lima dimensi yang harus ada yaitu: Pertama, adanya integrasi pendidikan dalam kurikulum (content integration) yang di dalamnya melibatkan keragaman dalam satu kultur pendidikan yang tujuan utamanya adalah menghapus prasangka. Kedua, konstruksi ilmu pengetahuan atau knowledge construction yang diwujudkan dengan mengetahui dan memahami secara komperhensif keragaman yang ada. Ketiga, pengurangan prasangka atau prejudice reduction yang lahir dari interaksi antarkeragaman dalam kultur pendidikan. Keempat, pedagogik kesetaraan manusia atau equity pedagogy yang memberi ruang dan kesempatan yang sama kepada setiap elemen yang beragam. Kelima, pemberdayaan kebudayaan sekolah atau empowering school culture. Hal yang kelima ini adalah tujuan 
Musyarofah, Internalisasi Pesan Multikultural Pada Organisasi Pesantren...

dari pendidikan multikultur yaitu agar sekolah menjadi elemen pengentas sosial atau transformasi sosial dari struktur masyarakat yang timpang kepada struktur yang berkeadilan.

\section{Pendekatan Pendidikan Multikultural}

Mendesain pendidikan multikultural dalam tatanan masyarakat yang penuh permasalahan antar kelompok, budaya, suku dan lain sebagainya. Indonesia memiliki tantangan yang tidak ringan. Perlu disadari bersama, bahwa pendidikan multikultural tidak hanya sebatas 'merayakan keragaman'. Apalagi, jika tatanan masyarakat yang ada masih penuh diskriminasi dan bersifat rasis. Choirul Mahfud (2013:193) mengemukakan beberapa pendekatan dalam proses pendidikan multikultural yaitu: Pertama, tidak lagi menyamakan pandangan pendidikan dengan persekolahan atau schooling, atau pendidikan multikultural dengan program-program sekolah formal. Pandangan yang lebih luas mengenai pendidikan sebagai transmisi kebudayaan membebaskan pendidik dari asumsi keliru bahwa tanggung jawab primer mengembangkan kompetensi kebudayaan dikalangan anak didik semata-mata berada di tangan mereka, tapi justru semakin banyak pihak yang bertanggung jawab, karena program-program sekolah seharusnya terkait dengan pembelajaran informal di luar sekolah.

Kedua, menghindari pandangan yang menyamakan kebudayaan dengan kelompok etnik. Artinya, tidak perlu lagi mengasosiasikan kebudayaan semata-mata dengan kelompok-kelompok etnik sebagaimana yang terjadi selama ini. Secara tradisional, para pendidik lebih mengasosiasikan kebudayaan dengan kelompokkelompok sosial yang relatif self sufficient, ketimbang dengan sejumlah orang yang secara terus-menerus dan berulang-ulang terlibat satu sama lain dalam satu atau lebih kegiatan. Dalam konteks pendidikan multikultural, pendekatan ini diharapkan dapat mengilhami para penyusun program pendidikan multikultural untuk melenyapkan kecenderungan memandang anak didik secara stereotipe menurut identitas etnik mereka; sebaliknya mereka akan meningkatkan eksplorasi pemahaman yang lebih besar mengenai kesamaan dan perbedaan di kalangan anak didik dari berbagai kelompok etnik.

Ketiga, karena pengembangan kompetensi dalam suatu 'kebudayaan baru' biasanya membutuhkan interaksi inisiatif dengan orang-orang yang sudah memiliki kompetensi, maka dapat dilihat lebih jelas bahwa upaya untuk mendukung sekolahsekolah yang terpisah secara etnik merupakan antithesis terhadap tujuan pendidikan 
Inject, Interdisciplinary Journal of Communication, Vol. 1, No. 2, Desember 2016:181-202

multikultural. Mempertahankan dan memperluas solidaritas kelompok akan menghambat sosialisasi kedalam kebudayaan baru. Pendidikan bagi pluralisme budaya dan pendidikan multikultural tidak dapat disamakan secara logis.

Keempat, pendidikan multikultural meningkatkan kompetensi dalam beberapa kebudayaan. Kebudayaan mana yang akan diadopsi, itu ditentukan oleh situasi dan kondisi secara proporsional. Kelima, kemungkinan bahwa pendidikan baik formal maupun non formal meningkatkan kesadaran tentang kompetensi dalam beberapa kebudayaan. Kesadaran seperti ini kemudian akan menjauhkan dari konsep dwi budaya atau dikotomi antara pribumi dan non-pribumi. Dikotomi semacam ini akan membatasi individu untuk sepenuhnya mengekspresikan diversitas kebudayaan. Pendekatan ini meningkatkan kesadaran akan multikulturalisme sebagai pengalaman normal manusia. Kesadaran ini mengandung makna bahwa pendidikan multikultural berpotensi untuk menghindari dikotomi dan mengembangkan apresiasi yang lebih baik malalui kompetensi kebudayaan yang ada pada diri anak.

Pengembangan kurikulum yang berdasarkan pendekatan pluralis-multikultural dapat dilakukan melalui langkah-langkah sebagai berikut; Pertama, mengubah filosofi kurikulum yang berlaku seragama; Kedua, Konten kurikulum harus pula diarahkan kepada pengertian yang mencakup nilai, moral, prosedur, proses dan keterampilan yang harus dimiliki anak didik; Ketiga, Teori belajar yang dipergunakan dalam kurikulum harus memerhatikan keragaman sosial, budaya, ekonomi, dan politik; Keempat, Proses belajar yang dikembangkan anak didik juga harus didasarkan proses yang memiliki tingkat isomorphism yang tinggi dengan kenyataan sosial; Kelima, Evaluasi yang digunakan harus meliputi keseluruhan aspek kemampuan dan kepribadian peserta didik sesuai dengan tujuan dan konten yang dikembangkan (Naim dan Sauqi, 2011:199).

\section{Materi dalam Kurikulum Pendidikan Multikultural}

Komponen inti lain dari kurikulum pendidikan multikultural adalah materi atau content. Dari segi materi, kurikulum dapat didefinisikan sebagai isu, tema, topik, dan konsep-konsep yang akan disampaikan oleh pendidik kepada peserta didik. Karena penekanannya pada materi, maka Gary Burnett menyebut kurikulum model ini dengan sebutan kurikulum yang berorientasi pada materi atau content oriented program.

Kurikulum pendidikan multikultural model ini, menurut Burnett, mengambil bentuk yang cukup sederhana yaitu dengan cara menambahkan isu-isu dan konsep- 
konsep multikultural pada kurikulum yang sudah ada. Isu dan konsep multikultural yang ditambahkan tersebut dapat menggunakan bacaan-bacaan tertentu yang berisi tentang sejarah para pahlawan dari berbagai etnik dalam kurikulum pendidikan. Tujuan utama dari kurikulum pendidikan multikultural model ini adalah untuk memasukkan materi tentang kelompok kultural yang beragam dalam kurikulum dan program pendidikan, agar pengetahuan peserta didik tentang beragam kelompok tersebut meningkat.

Kurikulum pendidikan multikultural yang berorientasi pada materi setidaknya dapat dilakukan dengan mengintegrasiakan materi multikultural (content integration) ke dalam kurikulum. Untuk kepentingan ini, ada dua tahap yaitu: tahap penambahan atau additive level dan tahap perubahan atau transformative level. Tahap penambahan, pengembangan kurikulum pendidikan multikultural dilakukan dengan cara memperkenalkan konsep dan tema-tema baru yang terkait dengan multikulturalisme ke dalam kurikulum yang sudah ada.

Cara ini sangat mudah dilakukan karena tanpa mengubah struktur kurikulum yang sudah ada. Sementara itu, tahap perubahan, karena pengembangan kurikulum multikultural dilakukan dengan cara memasukkan konsep dan tema-tema yang berkaitan dengan multikulturalisme serta memasukkan beragam cara pandang dan perspektif kedalam kurikulum. Cara ini lebih sulit dari pada cara pada tahap pertama, karena dilakukan dengan mengubah struktur kurikulum yang sudah ada.

Burnett dan Banks tidak memberi penjelasan secara rinci tentang cara memilih materi pendidikan yang berperspektif multikultural. Mereka hanya menjelaskan secara garis besar bahwa materi yang dapat diintegrasikan ke dalam kurikulum multikultural adalah isu, tema, topik, dan konsep-konsep yang berkaitan dengan multikulturalisme. Kurikulum berbasis multikultural perlu memasukkan materi dan bahan ajar yang berorientasi pada penghargaan kepada orang lain. Dalam hubungan ini, James Lynch (1986: 86-7) merekomendasikan agar sekolah atau guru menyampaikan pokok-pokok bahasan multikultural, dengan berorientasi pada 2 (dua) tujuan, yaitu: (a) penghargaan kepada orang lain (respect for others), dan (b) penghargaan kepada diri sendiri (respect for self). Adapun pakar pendidikan multikultural yang menjelaskan secara detail tentang materi yang dapat diintegrasikan dalam kurikulum multikultural adalah Donna $\mathrm{M}$. Gollnick dan Philip C.Chinn. Menurut mereka, konsep-konsep yang dapat dimasukkan kedalam kurikulum pendidikan multikultural adalah rasisme, seksisme, prasangka, 
Inject, Interdisciplinary Journal of Communication, Vol. 1, No. 2, Desember 2016:181-202

diskriminasi, penindasan, ketidakberdayaan, ketidakadilan kekuasaan, keadilan dan stereotip.

\section{Pengertian Pesantren}

Kata pesantren secara etimologis berasal dari pe-santri-an yang berarti tempat santri; asrama tempat santri belajar agama atau; pondok. Dikatakan pula, pesantren berasal dari kata santri, yaitu seorang yang belajar agama Islam, dengan demikian pesantren mempunyai arti tempat orang berkumpul untuk belajar agama Islam (Daulay, 2001:7). Disisi lain ada yang berpendapat bahwa kata 'santri' berasal dari bahasa India atau Sansekerta 'shastri' yang berarti ilmuwan Hindu yang pandai menulis, melek huruf atau kaum literasi atau kaum terpelajar.

Pesantren adalah lembaga pendidikan tradisional umat islam untuk mempelajari, memahami, memdalami, menghayati, dan mengamalkan ajaran agama Islam dengan memberikan penekanan pada keseimbangan antara aspek ilmu dan perilaku (Ensiklopedi Indonesia, 1990:187). Pesantren merupakan institusi sosial keagamaan yang menjadi wahana pendidikan bagi umat Islam yang ingin mendalami ilmu-ilmu keagamaan. Pondok pesantren dalam terminologi keagamaan merupakan institusi pendidikan Islam, namun demikian pesantren mempunyai icon sosial yang memiliki pranata sosial di masyarakat. Hal ini karena pondok pesantren memiliki modalitas sosial yang khas, yaitu: 1) ketokohan Kyai, 2 ) santri, 3) independen dan mandiri, dan 4) jaringan sosial yang kuat antar alumni pondok pesantren (Mun'im, 2009:1).

Pesantren merupakan lembaga pendidikan yang sangat berakar dari masyarakat. Kiai pendiri sebuah pesantren akan hidup berinteraksi dengan masyarakat sekitar, dan masyarakatpun merasa memilikinya. Kegiatan utama yang dilakukan dalam pesantren adalah pengajaran dan pendidikan Islam. Hal ini menuntut kualitas seorang kiai tidak sekedar sebagai seorang ahli tentang pengetahuan keislaman yang mumpuni, tetapi juga sebagai seorang tokoh panutan untuk diteladani dan diikuti. Melalui kegiatan ajarbelajar, seorang kiai mengajarkan pengetahuan keislaman tradisional kepada para santrinya yang akan meneruskan proses penyebaran islam tradisional (Effendi, 2010:41).

Secara umum, pesantren memiliki tipologi yang sama, yaitu sebuah lembaga yang dipimpin dan diasuh oleh kiai dalam satu komplek yang bercirikan: adanya masjid atau surau sebagai pusat pengajaran dan asrama sebagai tempat tinggal santri, di samping rumah tempat tinggal kiai, dengan "kitab kuning" sebagai buku pegangan. Kitab kuning 
adalah faktor penting yang menjadi karakteristik pesantren. Selain sebagai pedoman bagi tata cara keberagamaan, kitab kuning difungsikan oleh kalangan pesantren sebagai referensi (marji') nilai universal dalam menyikapi segala tantangan kehidupan (Mahmud, 2012:235). Dari pendapat tersebut dapat diketahui bahwa komponen pesantren mencakup; pondok, masjid, kiai, santri, dan pengajaran kitab kuning (kitab islam klasik). Pesantren akrab dengan khazanah klasik, yang mampu melahirkan sikap tasamuh (lapang dada), tawazun (keseimbangan), dan i'tidal (adil).

Pesantren sebagai institusi pendidikan islam tradisional, keberadaannya telah lama survie dalam sejarah perkembangan pendidikan Indonesia. Pesantren terbukti banyak memberikan sumbangan bagi upaya mewujudkan tujuan pendidikan nasional, yang bukan sekedar meningkatkan kualitas sumber daya manusia pada aspek pengetahuan dan tehnologi saja, melainkan juga lebih concern dalam mencetak warga negara Indonesia yang bertakwa kepada Tuhan Yang Maha Esa, serta memupuk generasi yang bermoral baik (akhlaq al-karimah). Hal tersebut sejalan dengan pendapat Azyumardi Azra (2003: 149) bahwa fungsi dan peran sosial pesantren terletak pada 3 (tiga) hal yaitu: (1) sebagai tempat terselenggaranya kegiatan transmisi dan transfer ilmu pengetahuan Islam, (2) sebagai pusat pemeliharaan tradisi Islam, dan (3) sebagai pusat penyiapan dan penciptaan kader-kader Islam.

\section{Kurikulum Pesantren}

Studi-studi pesantren tidak menyebut kurikulum yang baku dikalangan pesantren. Hal ini dapat dipahami karena pesantren sesungguhnya merupakan lembaga pendidikan Islam di Indonesia yang bebas dan otonom. Dari segi kurikulum, pesantren selama ini diberi kebebasan oleh negara untuk menyusun dan melaksanakan kurikulum secara bebas dan merdeka. Namun demikian, jika dilihat dari studi-studi tentang pesantren diperoleh bentuk-bentuk kurikulum yang ada dikalangan pesantren.

Menurut Lukens-Bull, secara umum kurikulum pesantren dapat dibedakan menjadi empat bentuk, yaitu: (1) pendidikan agama, (2) pengalaman dan pendidikan moral, (3) sekolah dan pendidikan umum (4) keterampilan dan kursus. Pertama, kurikulum berbentuk pendidikan agama Islam. Dalam dunia pesantren, kegiatan belajar pendidikan agama Islam lazim disebut dengan ngaji atau pengajian. Kegiatan ngaji di pesantren dalam praktiknya dapat dibedakan menjadi dua tingkatan. Tingkatan paling awal ngaji sangatlah sederhana, yaitu para santri belajar bagaimanacara membaca teks- 
Inject, Interdisciplinary Journal of Communication, Vol. 1, No. 2, Desember 2016:181-202

teks Arab, terutama sekali al-Quran. Tingkatan ini dianggap sebagai usaha minimal dari pendidikan agama yang harus dikuasai oleh para santri. Tingkatan berikutnya adalah para santri memilih kitab-kitab Islam klasik dan mempelajarinya dibawah bimbingan kiyai. Adapun kitab-kitab yang dijadikan bahan untuk ngaji meliputi bidang ilmu: fikih, akidah atau tauhid, nahwu, sharaf, balaghah, hadis, tasawuf, akhlak, dan ibadah-ibadah seperti shalat, doa, dan wirid. Menurut Van Bruiessen, ada sebilan ratus kitab kuning yang dipakai di pesantren. Hampir lima ratus buah kitab-kitab tersebut ditulis oleh ulama Asia Tenggara, dengan bahasa yang beragam: bahasa Arab, Melayu, Jawa, Sunda, Madura, Indonesia, dan Aceh.

Dalam dunia pesantren, posisi kitab kuning sangat strategis karena kitab kuning dijadikan sebagai text books, references, dan kurikulum dalam sistem pendidikan pesantren. Selain sebagai pedoman bagi tata cara keberagaman, kitab kuning difungsikan juga oleh kalangan pesantren sebagai referensi nilai universal dalam menyikapi segala tantangan kehidupan. Menurut Affandi Mochtar, ada 2 (dua) alasan yang mendasari pentingnya posisi kitab kuning sebagai referensi dan kurikulum dalam sistem pendidikan pesantren. Alasan yang pertama adalah bahwa kebenaran kitab kuning bagi kalangan pesantren merupakan referensi yang kandungannya sudah tidak perlu dipertannyakan lagi. Kenyataan bahwa kitab kuning yang ditulis sejak lama dan terus dipakai dari masa ke masa menunjukkan bahwa kitab kuning sudah teruji kebenarannya dalam sejarah yang panjang. Kitab kuning dipandang sebagai pemasok teori dan ajaran yang bersandar pada al-Quran dan Hadis Nabi. Alasan kedua adalah bahwa kitab kuning sangatlah penting bagi pesantren untuk memfasilitasi proses pemahaman keagamaan yang mendalam sehingga mampu merumuskan penjelasan yang segar tetapi tidak ahistoris mengenai ajaran Islam, al-Quran, dan Hadis Nabi.

Kedua, kurikulum berbentuk pengalaman dan pendidikan moral. Pesantren menempatkan pengalaman dan pendidikan moral sebagai salah satu kegiatan pendidikan penting di pesantren. Kegiatan-kegiatan keagamaan yang paling ditekankan di pesantren adalah kesalehan dan komitmen para santri terhadap lima rukun Islam yaitu; syahadat (keimanan), shalat, zakat, puasa, dan haji ke Mekah bagi yang mampu. Kegiatankegiatan tersebut diharapkan dapat menumbuhkan kesadaran para santri untuk mengamalkan nilai-nilai moral yang diajarkan pada saat ngaji. Adapun nilai-nilai moral yang ditekankan pada saat di pesantren adalah persaudaraan Islam, keikhlasan, kesederhanaan, dan kemandirian. Para santri mempelajari moralitas saat mengaji dan 
Musyarofah, Internalisasi Pesan Multikultural Pada Organisasi Pesantren...

kemudian diberi kesempatan untuk mempraktikkan. Dalam kaitan ini, Lukens-Bull menulis sebagai berikut:

"Sebagai contoh, shalat lima kali sehari adalah kewajiban dalam Islam, tetapi kadang belum menekankan pada pentingnya berjama'ah. Bagaimanapun, berjama'ah dianggap sebagai cara yang lebih baik dalam shalat dan pada umumnya diwajibkan di pesantren. Sebuah pesantren yang tidak mewajibkan shalat berjama'ah dianggap bukan lagi pesantren yang sebenarnya.Para kiyai mengatakan bahwa praktik jamaah ini mengajarkan persaudaraan dan kebersamaan, yaitu nilai-nilai yang harus ditumbuhkan dalam masyarakat Islam. Jika jamaah sekali dalam seminggu dalam shalat jum'at akan membentuk masyarakat yang solid, maka berjama'ah tiap hari akan memperkuat tali persaudaraan."

Adapun nilai keikhlasan dan kesederhanaan umumnya dibiasakan di pesantren melalui kebersamaan. Hal ini dapat dilihat dari peralatan tidur, kamar tidur, jenis makanan, dan lauk-pauknya, serta gaya hidup para santri di pesantren. Dilihat dari peralatan tidurnya, para santri tidur di atas lantai dalam satu ruangan yang mampu menampung enampuluh sampai delapanpuluh santri. Sebuah kamar yang umumnya dihuni satu sampai dua orang, ternyata di pesantren dihuni enam sampai delapan orang. Jika dilihat dari jenis makanan dan lauk-pauknya, para santri makan nasi putih dengan sayur dan lauk pauk seadanya. Gaya hidup dan cara berpakaian mereka juga sangat sederhana. Mereka sehari-hari memakai pakaian baju, sarung dan kopiah yang dari tahun ketahun tidak mengalami perubahan. Pengalaman seperti ini diterima oleh para santri dengan ikhlas, tanpa ada protes sekalipun. Adapun nilai kemandirian diajarkan di pesantren dengan cara santri mengurusi sendiri kebutuhan-kebutuhan dasarnya, seperti memasak, mencuci sendiri, menyetrika dan marawat barang miliknya masing-masing.

Ketiga, kurikulum berbentuk sekolah dan pendidikan umum. Pesantren memberlakukan kurikulum sekolah dengan mengacu kepada pendidikan nasional yang dikeluarkan oleh Departemen Pendidikan Nasional, sedangkan untuk kurikulum madrasah mengacu kepada pendidikan agamayang dikeluarkan oleh Departemen Agama. Jika dilihat dari rasio pendidikan umum dan pendidikan agama yang termuat di dalamnya, maka dapat dikatakan bahwa kurikulum sekolah cenderung sekuler. Dikatakan cenderung sekuler, karena dari keseluruhan total jam pelajaran yang ada, kurikulum sekolah hanya memberikan 2 jam pelajaran agama untuk setiap minggunya. Hal ini tentu berbeda dengan kurikulum madrasah yang memuat tujuh puluh persen untuk pendidikan agama dan tiga puluh persen sisanya untuk pendidikan umum. Karena 
Inject, Interdisciplinary Journal of Communication, Vol. 1, No. 2, Desember 2016:181-202

itu, kurikulum madrasah dapat dikatakan sebagai kurikulum yang memadukan antara yang sekuler dan yang agamis.

Bentuk kurikulum sekolah dan pendidikan umum ini, menurut Mastuhu, memiliki 2 (dua) keuntungan, yaitu: yang pertama keuntungan bagi pesantren dan yang kedua keuntungan bagi pendidikan nasional. Bagi pesantren, kedua bentuk kurikulum tersebut menjadi jembatan yang menghubungkan pesantren dengan sistem pendidikan nasional. Sebaliknya, bagi pendidikan nasional, kedua bentuk kurikulum tersebut memperoleh penyempurnaan dari sistem pendidikan pesantren terutama tentang pembinaan moral santri. Dengan, demikian ada hubungan yang saling menguntungkan antara sistem pendidikan pesantren dan sistem pendidikan nasional.

Mastuhu berpendapat bahwa terjadi simbiosis mutualisme kurikulum antara ketiga jenis pendidikan tersebut: pesantren, madrasah, dan sekolah umum. Dengan kata lain, makna "pesantren" sebagai jenis pendidikan non-formal, berbeda dengan makna pendidikan non-formal dalam term pendidikan umum; dimana makna pendidikan nonformal dalam term terakhir berarti memberikan komplemen dan suplemen pada keterampilan atau kemampuan yang telah dimiliki anak didik agar lebih mampu melayani kebutuhan yang semakin meningkat sehubungan dengan semakin kompleksitasnya tantangan pekerjaan yang dihadapinya. Sedangakan makna pendidikan non-formal pada pesantren berarti mendasari, menjiwai, dan melengkapi akan nilai-nilai pendidikan non-formal. Tidak semua hal dapat diajarkan atau dididikkan melalui program-program sekolah formal; di sini "pesantren" mengisi kekurangan tersebut."

\section{Metode Penelitian}

Dalam penelitian ini menggunakan pendekatan kualitatif fenomenologis yaitu untuk menggambarkan, mengungkap, dan menjelaskan internalisasi pendidikan multikultural pada santri di Organisasi Pesantren Putri STAIN Jember. Penelitian ini dilakukan pada Organisasi Pesanten Putri STAIN Jember, yang terletak di dalam komplek kampus STAIN Jember, yaitu di Jalan Jum'at No. 94 Mangli Jember selama empat bulan.

Penetapan subyek penelitian atau informan dipilih subyek pertama sebagai informan kunci yaitu informan yang didasarkan pertimbangan tertentu memenuhi syarat sebagai informan yang sangat mengetahui aspek-aspek permasalahan yang diteliti, bahkan sebagai pelaku dalam internalisasi nilai multikultural pada santri. Subyek 
penelitian sebagai informan dalam penelitian ini terdiri dari pengasuh, ustad atau ustadzah, pengurus, dan para santri di OPP STAIN Jember. Teknik pengumpulan data yang dipakai dalam penelitian ini adalah observasi partisipasi, wawancara mendalam atau in-depth interviewing dan teknik dokumentasi. Analisis data yang digunakan adalah model analisis interaktif atau component of analysis: Interactive model atau dapat digambarkan sebagai berikut:

\section{Gambar 1}

Model Analisis Interaktif Miles dan Huberman



Internalisasi Pendidikan Multikultural Pada Kurikulum di Organisasi Pesantren Puteri STAIN Jember.

Internalisasi pendidikan multikultural pada kurikulum di pesantren putri STAIN Jember dilaksanakan melalui kurikulum kegiatan diniyah pada malam hari dan ba'da subuh melalui kajian kitab. Berdasarkan hasil wawancara dengan pengasuh, dan santri serta analisis kurikulum pesantren diketahui bahwa nilai-nilai multikultural pada kurikulum diajarkan pada kajian Taisirul Kholaq, Tadhib, Al-Akhlaqu Lil Banats, Fiqhun nisa', Kifayatu al-atsqiya', dan Fathul Qorib.

Pada kajian kitab Taisirul Kholaq misalnya, selain berbicara tentang takwa, adab guru, adab murid, hak orang tua, terdapat bab yang membahas tentang etika dalam pergaulan, ramah tamah, persaudaraan (saling mengasihi), dan adil pada semua orang tanpa membeda-bedakan agama, budaya dan sebagainya. Ketika santri belajar kitab 
Inject, Interdisciplinary Journal of Communication, Vol. 1, No. 2, Desember 2016:181-202

kuning dalam materi fiqih, misalnya, maka di sini santri secara tidak langsung akan menemukan pembelajaran tentang perbedaan.

Dalam kitab fiqih, santri akan menemukan beragam pendapat tentang hukum dalam Islam. Dari kesemuanya itu dapat membekali santri memiliki kompetensi multikultural, sehingga dapat bersikap toleran satu sama lain. Sedangkan pada program pagi dengan kurikulum STAIN ada beberapa mata kuliah yang ditempuh santri dan didalamnya memiliki muatan pendidikan multikultural yaitu Sosio-antropologi, Akhlak, Pendidikan Kewarganegaraan (PKn), Sejarah Peradaban Islam, hadits I, II, Fiqih, dan tasawuf.

Kurikulum pendidikan multikultural yang berorientasi pada materi dapat dilakukan dengan mengintegrasikan materi multikultural (content integration) ke dalam kurikulum. Untuk kepentingan ini, akan memberikan dua tahap, yaitu: tahap penambahan (additive level) dan tahap perubahan (transformative level). Dikatakan tahap penambahan, karena pengembangan kurikulum pendidikan multikultural dilakukan dengan cara memperkenalkan konsep dan tema-tema baru yang terkait dengan multikulturalisme ke dalam kurikulum yang sudah ada. Cara ini sangat mudah dilakukan karena tanpa mengubah struktur kurikulum yang sudah ada.

Sementara itu, dikatakan tahap perubahan, karena pengembangan kurikulum multikultural dilakukan dengan cara memasukkan konsep dan tema-tema yang berkaitan dengan multikulturalisme serta memasukkan beragam cara pandang dan perspektif kedalam kurikulum. Cara ini lebih sulit dari pada cara pada tahap pertama, karena dilakukan dengan mengubah struktur kurikulum yang sudah ada.

\section{Integrasi Pesan Multikultural dalam Pengasuhan di Organisasi Pesantren Putri STAIN Jember}

Di kalangan santri pesantren putri OPP STAIN sangat memahami bahwa perbedaan adalah rahmat. Mereka menyadari bahwa keragaman dalam pandangan Islam adalah sunatullah. Realitas keragaman agama dan budaya di kalangan umat manusia merupakan fakta yang tidak mungkin diingkari. Sebenarnya, pembawaan Islam yang semacam inilah yang cocok untuk kultur Indonesia, mengingat negara ini masyarakatnya terdiri dari berbagai agama, suku, dan sangat lengkap dengan perbedaan. Islam yang ramah, tidak kaku, moderat, Islam mampu memahami adanya perbedaan, dan sarat dengan nilai-nilai multikultural. 
Dari integrasi nilai-nilai multikultural dalam pengasuhan dilaksanakan melalui antara lain: Pertama menciptakan kultul pesantren yang menghargai perbedaan; Kedua kegiatan pengasuhan yang dilakukan pak kyai menekankan pentingnya aspek penghargaan terhadap kemanusiaan; Ketiga pemberlakuan tata tertib dan sanksi yang diperuntukkan bagi semua santri, tanpa memandang latar belakang status sosialekonomi.

Paparan di atas menunjukkan bahwa internalisasi nilai-nilai multikultural pada santri dilakukan secara komprehensif baik melalui kegiatan pengasuhan maupun pendidikan, sehingga mampu melahirkan sikap tasamuh (lapang dada), tawazun (keseimbangan), dan i'tidal (adil). Hal tersebut menunjukkan adanya keinginan yang kuat pengasuh pada proses pengembangan kemampuan santri untuk memahami, mengakui, menghormati dalam realitas perbedaan. Pendidikan multikultural dapat mencetak santri mempunyai kearifan lokal, mempunyai jiwa toleransi, atau menghasilkan santri yang berpandangan inklusif.

\section{Peran Pengasuh dan Pengurus dalam Menginternalisasikan Pesan Multikultural pada Santri di Organisasi Pesantren Putri STAIN Jember}

Peran pengasuh dalam internalisasi nilai-nilai multikultural pada santri ada dua yaitu: peran langsung dan tidak langsung. Peran langsung pengasuh dapat dilihat dari visi kepemimpinan yang mengedepankan nilai-nilai multikultural, serta pada setiap kegiatan pengasuhan yang dilakukan oleh pengasuh yang sarat dengan nilai-nilai multikultural. Sedangkan peran pengurus dalam internalisasi nilai-nilai multikultural pada diri santri terlihat pada penegakan aturan dan sanksi yang berlaku untuk semua santri, bahkan apabila ada pengurus yang melanggar aturan dia akan mendapatkan sanksi yang lebih berat. Selain itu pengurus pada masing-masing divisi bertugas membuat program kegiatan dan mengkoordinir jalannya kegiatan yang diprogramkan.

OPP STAIN Jember sudah menunjukkan keinginan dan visi yang kuat untuk mendemonstrasikan bahwa Islam sebagai agama besar menjunjung tinggi dan menghargai kemajemukan. Visi seperti ini harus dapat disebarkan dan menjadi visi bersama komunitas pesantren dan umat Islam, karena multikulturalisme adalah sebuah keniscayaan seperti juga ditekankan dalam Al-Quran.

Untuk merealisasikan visi ini, maka strategi yang selaras perlu dikembangkan seiring dengan program-program yang berwawasan multikultural. Mengingat Pondok 
Inject, Interdisciplinary Journal of Communication, Vol. 1, No. 2, Desember 2016:181-202

pesantren memiliki tanggungjawab besar dan peran strategis dalam mengembangkan pendidikan Islam berwawasan multikultural. Hal ini disebabkan karena pondok pesantren merupakan lembaga pendidikan awal yang banyak mencetak agamawan dan intelektual muslim. Dan lembaga ini secara emosional dan kultural sangat erat kaitannya dengan masyarakat akar rumput. Untuk itu, lulusan pondok pesantren menjadi sangat strategis dalam perannya mengembangkan pendidikan Islam yang berwawasan multikultural. Mengingat nilai-nilai yang ditekankan pada saat di pesantren adalah persaudaraan, keikhlasan, kesederhanaan, dan kemandirian.

Pesantren mengemban fungsi utama sebagai lembaga pendidikan. Fungsi ini memiliki dua misi: Pertama, pendidikan umat secara umum untuk mendidik dan menyiapkan generasi muda islam menjadi umat berkualitas (khaira ummah) pelaksana misi amar ma'ruf nahi munkar dan generasi yang shalih. Kedua, sebagai lembaga pendidikan pengkaderan ulama, agent of exellence, dan pengembangan ilmu pengetahuan, khususnya ilmu agama. Dalam hal ini, tugas pesantren adalah mendidik dan menyiapkan thâifah mutafaqqihah fid-dîn, yaitu kader-kader ulama atau pengasuh pesantren yang mampu mewarisi sifat dan kepribadian para Nabi.

\section{Simpulan}

Dari uraian di atas dapat diambil kesimpulan sebagai berikut (1) internalisasi pendidikan multikultural pada kurikulum dilakukan pada kegiatan diniyah dan kajian kitab yaitu dengan mengintegrasikan nilai-nilai multikultural pada kajian Taisirul Kholaq, Tadhib, Al-Akhlaqu Lil Banats, Fiqhun nisa', Kifayatu al-atsqiya', dan Fathul Qorib. (2) Integrasi nilai-nilai multikultural dalam pengasuhan dilaksanakan melalui; Pertama, menciptakan kultul pesantren yang menghargai perbedaan; Kedua kegiatan pengasuhan yang dilakukan pak kyai menekankan pentingnya aspek penghargaan terhadap kemanusiaan; Ketiga pemberlakuan tata tertib dan sanksi yang diperuntukkan bagi semua santri, tanpa memandang latar belakang status sosial-ekonomi. (3) Peran pengasuh dalam internalisasi nilai-nilai multikultural pada diri santri ada dua yaitu; peran langsung dan tidak langsung.

Peran langsung pengasuh dapat dilihat dari visi kepemimpinan yang mengedepankan nilai-nilai multikultural, serta pada setiap kegiatan pengasuhan yang dilakukan, sedangkan peran tidak langsung pengasuh dapat dilihat pada tahap awal penerimaan santri baru dan pada pembentukan pengurus. Peran pengurus dalam 
Musyarofah, Internalisasi Pesan Multikultural Pada Organisasi Pesantren...

internalisasi nilai-nilai multikultural pada diri santri terlihat pada penegakan aturan dan sanksi yang berlaku untuk semua santri.

Internalisasi pendidikan multikultural pada santri akan tercapai secara optimal manakala diperhatikan sebagai berikut (1) Internalisasi pendidikan multikultural pada kurikulum perlu diintegrasikan dalam semua kajian kitab di kelas secara klasikal maupun sorogan, tidak sebatas pada materi pelajaran tertentu, sehingga penanaman nilai-nilai multikultural pada diri santri sampai dalam diri. (2) Internalisasi nilai-nilai multikultural dalam pengasuhan perlu dilakukan secara terus menerus baik secara langsung maupun tidak langsung.

\section{Daftar Pustaka}

Aly, Abdullah. 2011. Pendidikan Islam Multikultural di Pesantren Telaah Terhadap Kurikulum Pondok Pesantren Modern Islam Assalam Surakarta. Yogyakarta: Pustaka Pelajar.

Azra, Azyumardi. 2003. Surau: Pendidikan Islam Tradisional dalam Transisi dan Modernisasi. Jakarta: Logos.

Banks, James A. (ed.), 1989. Multicultural Education: Issues and Perspectives. BostonLondon: Allyn and Bacon Press.

Bennet, C.I, 1990. Comprehensip Multikultural Education. Boston: Allyn and Bacon.

Dawam, Ainurrafiq, 2003. Emoh Sekolah, Yogyakarta: Inspeal Ahimsa Karya Press.

Djohan Effendi, 2010. Pembaruan Tanpa Membongkar Tradisi: Wacana Keagamaan di Kalangan Generasi Muda NU Masa Kepemimpinan Gus Dur, Jakarta: Kompas,

Ensiklopedi Indonesia, 1990. Jilid XII.

Hadari Nawawi, 1993. Metodologi penelitian Terapan. Yogyakarta:Universitas Gajah Mada.

Mahfud, Choirul, 2009. Pendidikan Multikultural, Yogyakarta: Pustaka Pelajar.

Mahmud, 2012. Sosiologi Pendidikan. Bandung: Pustaka Setia.

Mastuhu, 1994. Dinamika Sistem Pendidikan Pesantren: Suatu Kajian Tentang Unsur dan Nilai Sistem Pendidikan Pesantren. Jakarta: INIS.

Miles, Matthew B. and Huberman, 1994. Qualitative data analysis: An expanded sourcebook. London: Sage publications.

Moleong, Lexy, 2000. Metodologi penelitian kualitatif. Bandung: PT Remaja Rosdakarya. Nasution, S, 1988. Metode penelitian naturalistik-kualitatif. Bandung: Tarsito. 
Inject, Interdisciplinary Journal of Communication, Vol. 1, No. 2, Desember 2016:181-202

Ngainun Naim dan Achmad Sauqi, 2008. Pendidikan Multikultural: Konsep dan Aplikasi, Yogyakarta: Ar-Ruzz Media.

Nieto, S. 1996. Affirming diversity: The sociopolitical context of multicultural education (2nd ed.). New York: Longman. 